"Synthesizing the economist's and the psychologist's approaches to litter control for sustainable waste management"

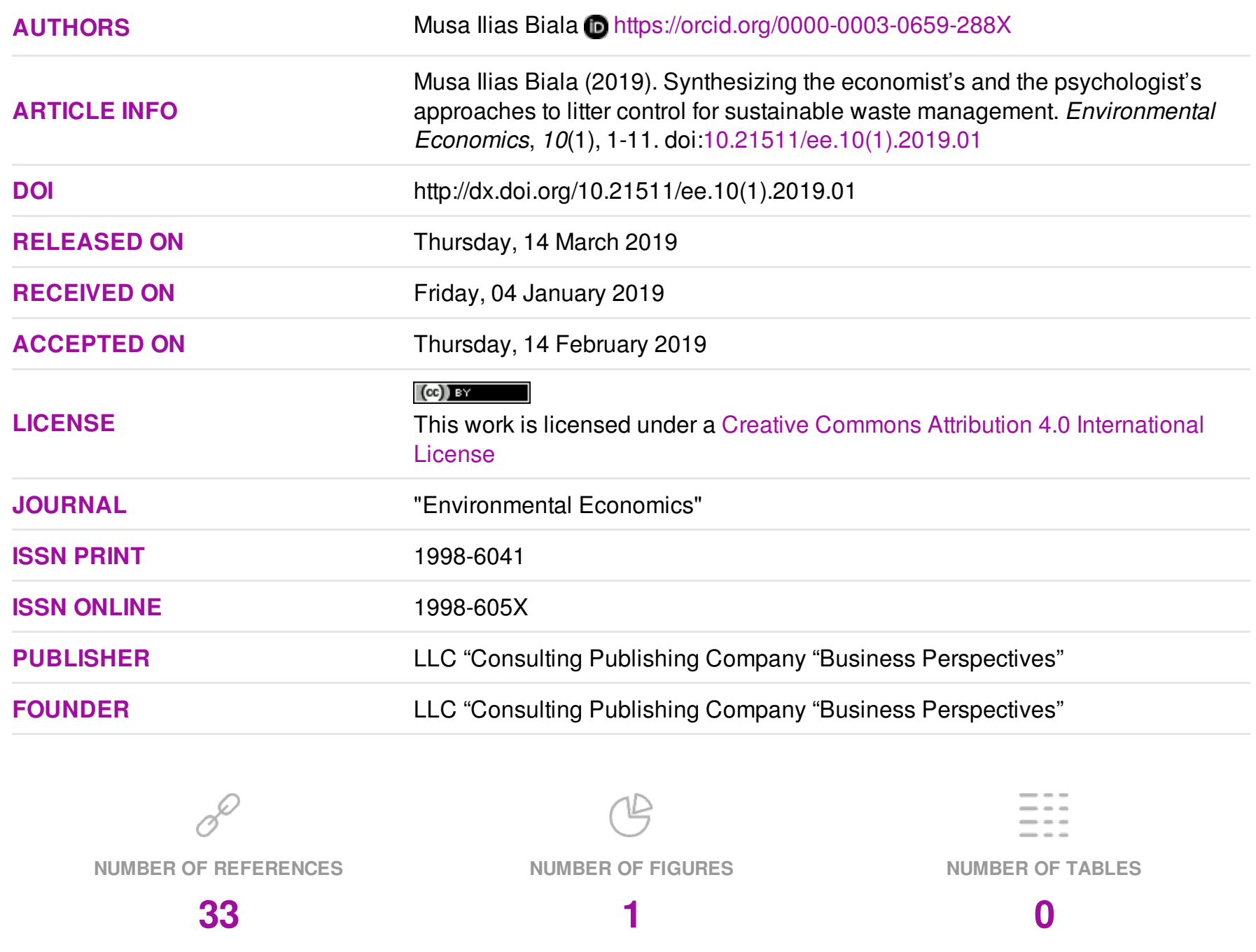

(C) The author(s) 2023. This publication is an open access article. 


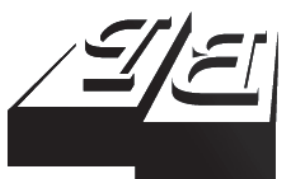

BUSINESS PERSPECTIVES

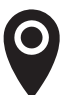

LLC "CPC "Business Perspectives" Hryhorii Skovoroda lane, 10, Sumy, 40022, Ukraine

www.businessperspectives.org

Received on: $4^{\text {th }}$ of January, 2019 Accepted on: 14 ${ }^{\text {th }}$ of February, 2019

(C) Musa Ilias Biala, 2019

Musa Ilias Biala, Ph.D., Department of Economics and Development Studies, Kwara State University, Malete, Nigeria.

\section{SYNTHESIZING THE ECONOMISTS AND THE PSYCHOLOGIST'S APPROACHES TO LITTER CONTROL FOR SUSTAINABLE WASTE MANAGEMENT}

\begin{abstract}
Littering has been a subject of inquiry by environmental economists, as well as social and environmental psychologists, each using a different theoretical and analytical toolkit. While economists see littering as an externality problem or a market failure, psychologists see it as a social behavior problem. Regardless of the discipline, both theories have a common goal: What factors affect littering behavior and how can it be curtailed? This paper, therefore, adopts theory-triangulation approach to review theories concerning littering. It concisely reviews the economist's and the psychologist's approaches to littering and their respective solutions. The finding from this review is that the psychological approaches to litter control are narrower in coverage than the economic approaches in that the former are applicable to smaller environmental settings or areas, such as school premises, office places, factories, and market places, as opposed to such lager settings as cities, states or the country at large to which economic instruments are usually applied. Despite the plethora of research extolling the virtues of economic approaches to litter control, their real-world application has not caught on. One of the factors found responsible for this is the implementation costs and difficulty involved. The economic instruments are costlier than the psychological instruments, because the former covers a larger setting and entail a lot of bureaucracies. To better understand littering and find appropriate solutions to it, studies on littering should consider looking at littering holistically from this interdisciplinary perspective. Both the economist's and the psychologist's approaches to litter control should be synthesized for sustainable waste management. However, policymakers need to consider the available financial resources and the multifarious views of litter in policies relating to litter. An option for policymakers is to minimize those costs associated with implementing economic instruments.
\end{abstract}

\section{Keywords}

\section{JEL Classification} of planned behavior, broken windows theory

\section{INTRODUCTION}

Litter is garbage that is thrown somewhere other than a garbage can. In other words, litter is any disposable item dumped in an inappropriate manner in an inappropriate place. National Environmental Standards and Regulations Enforcement Agency (2009) defines litter as any material left in a place other than receptacle or place intended or approved for receiving such material. It consists of packaging, paper and other materials that have been disposed of improperly. Litter results from production, consumption and careless handling of rubbish. It is one of the most neglected but most visible forms of environmental pollution and degradation (Finnie, 1973). Litter items can be discarded either actively or passively (Sibley \& Liu, 2003).

Litter constitutes an eyesore and is potentially dangerous. It decreases the aesthetic appeal of the environment and depresses business and 
property values. It flies about via wind and water to pollute water ways and ecosystems. Litter is one of the major constituents of land pollution and contributes to environmental degradation. It is produced by the collective action of many individuals rather than by a small number of firms or individuals (Finnie, 1973). Litter is multifarious and spacio-temporally dynamic - it changes in composition, time, space and volume. According to Egunjobi (2009), litter is the surface symptom of a diseased environment - a symptom of ailments of a city. Litter is moved by wind, water, animals or traffic until it is trapped somewhere. Litter is usually found trapped along fence lines, in culverts, in lawns, puddles and gutters. The task and cost of cleaning up litter on public places are usually the responsibility of the local government. When litter is curbed at its source, the cost of removal is much less than clearing it up after it has been generated and widespread.

Littering is mainly anthropocentric; it is rooted in human behavior. It is a convenient behavior repeated daily by people. It is pervasive, because it attracts high external costs, but zero disposal costs. It is a major cause of environmental degradation. Littering is an offence punishable by law, and the offenders are either fined or prosecuted. The offence of littering is commonly overlooked by the guardians of the law, because it is not considered as serious as offences such as murder, robbery, defrauding or defilement (Selby, 2012). Littering has long-term consequences on the environment and the lives of the people. It makes the environment filthy and unhygienic, resulting in different categories of diseases, sickness or infections, which in the long run increases the government expenditure on health.

\section{THEORETICAL BASIS}

\subsection{Economic theory of littering}

Neoclassical theory of externalities describes the economist's approach to litter and its control (see Solow, 1972). Environmental economists see litter as an instance of negative environmental externalities and thus as a source of a market failure. To them, litter is a negative environmental externality with negative impacts that reach far beyond the community of origin. An externality occurs when the production or consumption behavior of an economic agent favorably or adversely affects the welfare of another economic agent without adequate reflection of the effects in the market price of the good or service. This definition implies that an externality can be positive (favorable) or negative (adverse). However, this review focuses on the negative externalities, a classic example of which is litter.

The neoclassical theory of externalities describes that externalities are (1) not taken into account when the commodity is priced, (2) borne by a party other than the parties that are directly involved in the market transaction, and that (3) the ultimate consequence is a market failure - the inefficient allocation of resources by the market. This inability of the market to allocate resources efficiently usually results in an environmental problem, which could persist if the failure is not corrected. Neoclassical microeconomic theory identifies four basic sources of market failures - market imperfection (non-competitive behavior), externalities, public goods, and imperfect (or asymmetric) information - which differ according to the type of assumption of perfect market violated ${ }^{1}$. Each source results from the failure of each of the underlying assumptions of the perfectly competitive model and points to the need for government intervention in the economy (Case et al., 1999). If any of the assumptions of the perfectly competitive market is violated, the market forces cease to operate freely and the result will be a market failure, a typical source of which is externality, which in turn may result in an environmental problem. Neoclassical economists, notably Pigou (1920), recognized these inefficiencies associated with externalities as a form of market failure and advocated for government intervention via taxes (Thomas \& Callan, 2010).

1 Market imperfection means that single firms are large enough to have some control over price and potential competition. Existence of a public good means the failure of the market to produce everything that all members of a society want. Efficiency requires price $=$ marginal cost $=$ marginal social cost $=$ marginal private cost + marginal external cost . But in the presence of negative externalities, price $=$ marginal cost $=$ marginal private cost. Imperfect information arises when the producers and consumers do not have full knowledge of product characteristics, available prices, costs, etc. This can lead to transactions that are disadvantageous. 
According to the neoclassical theory of externality, what causes a negative externality such as litter is the divergence between the private and social costs of producing a good that generates the externality (Thomas \& Callan, 2010). For an economy to achieve an efficient allocation, all costs - both private and external costs - must be considered and incorporated into the decisions leading to the allocation. However, the price of a commodity that generates litter does not reflect the true costs of the commodity. It only reflects the private costs to the firm or the consumer; it does not reflect the external or environmental costs of producing the litter-generating product. The producers consider only the private cost of production without taking into account the external cost their production activity has on the society. This is because market does not always force consideration of all the costs while pricing a product. Hence, the price of the product will be very low. The lower the price, the more the commodity will be consumed and thus the more the externality will be generated.

This failure to internalize, or take account of, the external cost results in a market failure. Litter, for example, disrupts the smooth functioning of the market system. When litter externalities exist, markets do not produce socially optimal outcomes, because information being conveyed by the price of the litter-generating product is fundamentally inaccurate, thereby leading to an inefficient allocation of resources. The price mechanism allocates resources efficiently via prices and profits, the signals that determine the allocation; but if the prices do not reflect the full social costs, there is bound to be inefficient allocation of resources. This inefficient allocation of resources arising from litter externalities - termed market failure - is attributed to the divergence between the social cost and the private cost of production or consumption, which sends wrong price and profit signal to both consumers and producers.

As summarized by Tietenberg and Lewis (2009), the general postulates of the theory of externalities are that, for any negative externality-generating product, (1) the output produced will be excessively large, (2) excessive pollution externalities will be generated, (3) the product's price will be extremely low, (4) the externality-generating firms will exert no effort to generate optimal level of pollution as long as the costs are external, and (5) re- cycling of the product will be deterred, because its residues are disposed of virtually free of charge. In summary, whenever a product generates a negative externality, inordinate amount of the product will be produced at an extremely low price. This is illustrated in Figure 1.

Figure 1 models the case of a negative externality and depicts that when negative externalities exist, the marginal private cost (MPC) will be lower than the marginal social cost (MSC), the difference being the marginal external cost (MEC) imposed on the society. That is, MSC - MPC $=$ MEC, which implies that MSC $=$ PC + MEC. Likewise, marginal external benefit (MEB) plus marginal private benefit (MPB) equals marginal social benefit (MSB). In other words, MSB = MPB + MEB. Since $\mathrm{MEB}=0$ in the case of negative externalities, $\mathrm{MSB}=\mathrm{MPB}$. While the competitive equilibrium output is $Q^{c}$ obtained where MPC $=\mathrm{MPB}$, the efficient equilibrium output is $Q^{\mathrm{e}}$, which is lower and occurs at the point where MSC $=\mathrm{MPB}=$ demand (D). Note that $\mathrm{MSB}=\mathrm{MPB}=\mathrm{D}$.

As depicted in Figure 1, the values of an externality-generating good or service are usually underpriced (the competitive price $P^{c}$ being lower than the efficient $P^{e}$ ), because private costs, which are reflected in market prices, fall short of the social costs of production or consumption of the good or service. The market price $P^{c}$ is too low; it reflects only the MPC (one part of MSC) of production or consumption, but not the MEC, the other part of MSC. Only at the higher price $P^{e}$ will the efficient level of output be produced. This underpricing results in overproduction and overconsumption of the externality-generating goods, since the competitive equilibrium output $Q^{c}$ is greater than the efficient equilibrium output $Q^{e}$. This is because the good or service is cheaper to the producers and consumers; but it is not, from the societal viewpoint. The producers and consumers do not face the full consequences of their production and consumption or disposal choices and, thus, the market system does not yield a socially efficient outcome. The source of this inefficiency is the incorrect pricing of the good. It should be noted that optimality does not require that externalities be completely eliminated, but that the amount of externalities be consistent with the optimal amounts of the good that generates them. 


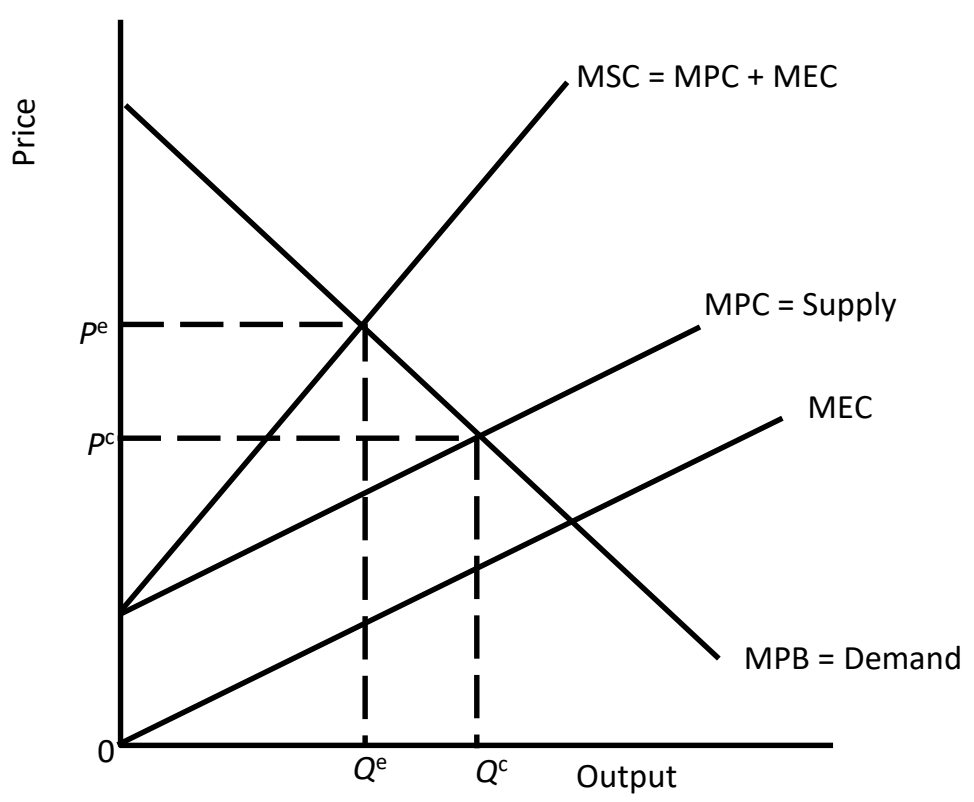

Figure 1. A model of negative externalities

The neoclassical theory of externality provides an insight into why environmental degradation occurs. The theory explains from a market perspective the persistence of environmental degradation and justifies the need for government to intervene where necessary. It considers environmental degradation as a consequence of market failure. The environment acts as a repository or sink into which litter and other wastes are ultimately discarded. Because this waste absorptive capacity of the environment is provided free of charge, excessive litter or wastes are discharged into the environment, thereby creating externality or imposing social cost on other users of the environment who are not part of the transactions that led to the waste generated (Solow, 1972). This is particularly true, because anything that is free is virtually always abused. Thus, the market failure resulting from externalities arise because the waste assimilative function performed by the environment is not priced or exchanged in the market and is, therefore, often not valued and accounted for in economic activities. If this function of the environment is priced, their use would have been different from what it is today. It is this treatment of the environmental function that results in a market failure (Eugine, 2004).

\subsubsection{Economic approaches to litter control}

How can the inefficiency - the market failure - resulting from an externality such as litter be rem- edied? Finding an appropriate solution to an environmental problem stems from an understanding of how and why the market fails (Thomas \& Callan, 2010). In the case of negative externalities, the market fails because of the divergence between private costs and social costs. Therefore, solutions to externality problems often require filling up this cost gap by internalizing the external costs in production and consumption decisions. This is achieved through the polluter-pays-principle (PPP): litterer-louts should be made responsible to bear the full external costs of their litter-generating activities, for externalities constitute a problem only if they are not taken into account by decisions makers. Thus, if the litterers pay for, or take into account, the negative externalities they create, the costs of consumption, which will then be private plus social costs, will be higher and so will the prices, and as such, less litter-generating products will be produced and consumed.

Several measures of internalizing external costs have been suggested in the literature. Pigou (1920) advocates the use of taxes and subsidies (now known as Pigouvian taxes and subsidies) to close the gap between private and social costs arising from externalities. That is, government should impose on litter a tax equal to the marginal external cost of litter. Imposing a tax on litter would equate net marginal private costs with net marginal social costs, and thus assures that market transac- 
tions lead to Pareto optimal outcomes (Andersen, 2001). When litter is priced (i.e., taxed), the result will be a more optimal allocation of resources than when it is not priced.

Later on, advance disposal fees (ADFs), recycling subsidies, and then deposit-refund system were proposed as litter-control measures. These internalization measures belong to a family of instruments called market-based instruments. The market-based instruments, or economic incentives more broadly, are instruments that use financial means or otherwise to motivate litterers to reduce litter (that is, to change their behavior indirectly). They are regulations that stimulate behavior through market signals rather than through command-and-control regulations (Stavins, 2001). Economic instruments aim to encourage a change of behavior - for example, from littering to antilittering - by internalizing environmental cost through a change in the incentive structure that the agents face. They harness the forces of the market to solve environmental problems by changing the prices that agents face. That is, they encourage pro-environmental behavior through market signals rather than through direct regulations. These instruments are briefly reviewed as follows.

\subsubsection{Advance disposal fees}

Advance disposal fees (ADFs) are a method of reducing litter in which is a fee is levied usually at the point of sales on a litter-generating-product to offset the disposal or cleanup cost of the litter generated by the product. The rationale behind ADFs is the polluter-pays-principle - that is, the costs of cleaning up litter should be borne by those responsible for the litter. The costs are usually captured in the product prices. Because an ADF is a charge on all the consumers of a product, it increases the price of the regulated product to both the litterers and non-litterers and thus provides an incentive for them to consider external costs when selecting a product.

ADFs promote recycling and source reduction - reductions in the quantity generated - of litter. They provide incentives for consumers of litter-generating products to switch their purchases to products that generate relatively less litter, and thereby reduce litter generation at source. ADFs provide these incentives by exempting from the fee products that generate relatively lower amount of litter or that meet certain levels of recycling and by increasing the base prices of those that do not. However, an ADF is an ex post measure, for it does not prevent littering; it only provides funds for litter cleanup. Although an ADF leads to source reduction, it fails to incentivize recycling (Walls, 2011). Therefore, a better alternative is required.

\subsubsection{Recycling subsidies}

Recycling subsidies are placed on recycling activities/processes and paid directly to recyclers for turning in waste materials and thus preventing litter. Recycling subsidies are the opposite of ADFs. Rather than imposing a fee on agents for cleaning up their litter, the recycling subsidy offers cash payments to litterers or consumers to incentivize them to recycle and thereby reduce litter. Those who litter forgo the cash payment. The recycling subsidy provides an incentive to litterers to control their litter whose marginal control cost is less than the subsidy. With recycling subsidies, litterers are rewarded for every unit of litter that they reduce by recycling.

Recycling subsidies increase recycling, but increase the volume of litter generated by lowering production costs through cheaper secondary materials. Thus, there is a need to use an instrument that provides incentives for both source reduction and recycling.

\subsubsection{Deposit-refund systems}

A deposit-refund system (DRS) is the economic instrument that combines the features of ADFs and recycling subsidies and thus provides incentives for both recycling and source reduction. A deposit-refund system is a market-based method of controlling litter in which the buyers of a litter-generating product pay a surcharge, which is later refunded when the used packaging of the product, or its residue, is returned to a point of purchase or a designated collection centre. The deposit levied on the litter-generating product is analogous to an ADF and is designed to cover the costs of litter cleanup in the event that the used packaging or leftovers are not returned for recycling; if returned, whoever turns in the packaging earns ei- 
ther a partial or total refund of the initial deposit. In other words, the refund represents a subsidy for waste-recovery effort.

A DRS is a stick-and-carrot way of internalizing the externalities arising from littering. Participating in a DRS implies paying a deposit (the stick) and getting a cash payment (the carrot) recycling - turning in the container. DRSs have the potential to effectively manage litter released from large numbers of small and dispersed sources (USEPA, 2001). As long as litterbugs bear the cost of littering, they have the incentive to return their used containers to collection centres. By doing so, they avoid the cost of littering and reap financial reward for recycling. The accompanied scavenging and returning of used containers provides a source of income for the low-income group in society.

DRSs are called for whenever there is massive littering and are more effective than other mechanisms for controlling litter. Several studies (for example, Dinan, 1993; Fullerton \& Kinnaman, 1995; Walls, 2011) have argued that the DRS is the best instrument that can achieve the social optimum in the presence of littering.

\subsection{Psychological theory of littering}

\subsubsection{Theory of reasoned action and theory of planned behavior}

The theory of reasoned action (TRA) and the theory of planned behavior (TPB) are well-established socio-psychological theories that provide a framework for explaining the determinants of behavior. The TRA views volitional behavior of an individual as being influenced by intention (the willingness to perform specific behavior), which, in turn, is influenced by the attitudes of the individual towards the behavior and the prevalent subjective norms (Fishbein \& Ajzen, 1975). The TPB was proposed in 1985 by Ajzen (1991) as an extension of TRA. The difference between the two theories is that in addition to attitude and subjective norm, the TPB adds the concept of perceived behavioral control to the TRA. The TRA is embedded in the TPB and both of them seek to understand factors that influence intentions to engage in certain behavior such as littering. Hence, a discussion of the TPB is essentially a discussion of the TRA.
The TPB posits that if people have a positive attitude towards a particular behavior, if they think their relevant others want them to perform the behavior, and if they believe they can perform the behaviour, then the intention to perform the behavior is heightened and, thus, the behavior will be performed. The TPB model consists of three important determinants of an intention to engage in a particular behavior (Ajzen, 1991):

1) the one's attitude or disposition towards the behavior. This refers to one's perceptions of the behavior;

2) the subjective or prevalent norm. This refers to the one's perception of normative or social pressure to engage in the behavior. It is guided by the behavior of other people;

3) the perceived behavioral control or self-efficacy. This is referred to as one's sense of whether one is capable of engaging in the behavior. It is the perceived ease/difficulty of performing the behavior. It reflects one's experience and anticipated impediments.

Going by the conceptual framework of the TPB, whether an intention to litter eventually results in littering depends on the actual behavioral control, which is influenced by factors such as convenience, knowledge, time, and availability of such facilities as trash receptacles (Wever et al., 2006).

The theory explains that the more favorable the attitude and the subjective norm towards a particular behavior and the greater the behavioral control, the stronger the intention to engage in the behavior. And the stronger the intention, the more likely the behavior is performed. Given this, if we wish to influence behavior, we cannot just limit ourselves to changing the environment and, therefore, the actual behavioral control people have in a particular situation, but we have to consider these three determinants of behavior altogether (Wever et al., 2006).

Social and environmental psychologists consider littering as a form of social behavior influenced by the above three independent concepts. Violation of social norms results in negative/positive consequences, depending whether the prevailing social norms are beneficial or harmful. 
However, Cialdini et al. (1990) contend that norms exert a great influence on littering behavior, and that the influence can only be appropriately recognized by (1) separating norms into what most other people do and what most other people approve or disapprove, which he termed, respectively, as descriptive norms and injunctive norm, and (2) focusing subjects' attention mainly on the type of norm being studied. If in an environment, littering is not acceptable and a person litters, the injunctive norms posit that the person will feel social disapproval from those watching him while he litters. However, "many people do not litter even if they know that nobody is observing them because littering imposes a feeling of guilt" (Rege \& Telle, 2001, p. 3). To Grasmick et al. (1991), feeling of shame and guilt restricts behavior, and increases the costs of noncompliance with the relevant law.

\subsubsection{Broken windows theory of littering}

Another theory used also by social psychologists to explain littering and its consequences is the broken windows theory (BWT) of crime propounded by two criminologists, James Wilson and George Kelling in 1982. The BWT is just a strand of TRA/ TPB: it considers social norm as the only factor affecting littering behavior. Wilson and Kelling (1982, p. 30) state specifically that "if the first broken window in a building is not repaired, then people who like breaking windows will assume that no one cares about the building and thus more windows will be broken. Soon the building will have no windows". The BWT explains the connection between disorder such as littering and crime (its consequences). It suggests that signs of disorder like litter, broken windows, and graffiti cause more disorder (Keizer et al., 2008).

The theory explains the maxim litter begets litter - few litter items invite more litter. A place that is already littered invites more litter. That is, litter attracts more litter. Some studies, for example, Cialdini et al. (1990), Keizer et al. (2008), KAB (2009), have found that the tendency to litter in an already littered environment is higher than in a clean environment. Individuals tend to act in accordance with the clear behavioral norm prevalent in the environment and hence the tendency to litter is due to imitations of social norm (Cialdini et al., 1990). The tendency to litter more in an al- ready littered environment is largely due to simple imitation in which an unpunished litterer would be expected to increase the littering tendencies of observers in either type of environment (Cialdini et al., 1990).

The tendency is also partly due to the tyranny of small decisions. The tyranny of small decisions occurs when individuals do not recognize that their actions (for example, littering) could be leading to a much larger problem. Thus, individuals are more likely to litter into an already littered environment because they want to imitate what others have already done, and after all, their own litter would do less damage to the already messy state of the environment than if it were clean (Robinson \& Ryan, 2002; Cialdini et al., 1990). Thus, littering is "communicable", for if some family members are in the habit of littering, other members of the same family are likely to litter (Calver, 1959).

The broken windows theory posits that more serious crimes evolve from minor infractions such as littering. More specifically, the contention is that littering causes more serious crimes: minor "disorders", such as littering, public urination, prostitution, and public drinking, may lead to more serious kinds of crimes. Keizer et al. (2008) argue that when low-level quality-of-life offenses are tolerated in a community, more serious crimes will follow.

Attributing the cause of large litter to already existing little litter, the broken windows theory suggests an antecedent strategy for litter control. Society should prevent a "window" from being broken in order to avoid having more windows broken, and if a window is already broken, it should be repaired on time. That is, minor disorders like broken windows, litter, and graffiti should be prevented from triggering more (major) disorders. Prevention of litter could take the form of information/education, messages/prompts, modeling and demonstrations, commitment, and environmental design.

\subsubsection{Psychological approaches to litter control}

According to TRA/TPB, solution to littering involves a behavioral change - a change in social norm by large number of people with little or 
no economic incentive to do so. Carlson (2001) describes this as large number, small payoff collective action problem, since the production of litter is a collective action refraining from littering can be seen as a kind of cooperative and social behavior, which can improve social capital. What is needed is a change from littering behavior to antilittering behavior. Since social norms influence littering behavior, the campaign against littering is a campaign against a social norm. As a result, environmental psychologists have suggested two broad behavioral intervention approaches to controlling litter: antecedent control strategies and consequence control strategies.

Antecedent strategies refer to measures that prevent the occurrence of an undesired behavior like littering. Consequence strategies, on the other hand, are measures taken after the behavior has been performed. The antecedent strategies stop behavior from happening in the first place, while the consequence techniques stop behavior from happening again in the future. These behavior-change intervention strategies can be conceptualized as antecedent-behavior-consequence $(\mathrm{ABC})$ model of behavioral change. Behaviors are directed by the antecedent stimuli that precede them and announce the availability of a positive or a negative consequence; and further occurrences of the behavior are determined by the consequences that follow (Lehman \& Geller, 2004).

A variety of antecedent strategies that have been suggested in the literature includes (1) information/education, (2) messages/prompts (verbal or written), (3) modeling and demonstrations, (4) commitment, and (5) environmental design. Information campaign involves the dissemination of information as a part of consciousness raising campaign that may generate desired behavioral changes. By providing information about the significance or negative effects of undesired behavior, pro-environmental behavior is encouraged. Educating litterers out of their habit, teaching people that casual littering can have serious impacts on the environment, their health and wildlife. There is some evidence that information and education may be effective in protecting the environment.
An extensive body of research has indicated that the provision of information and education to people can help reduce certain types of littering in certain types of settings. However, information campaigns alone have little chance of promoting environmental behavioral change. Educating the public on the need not to litter can be done in a variety of ways: (1) integrating littering and its impact into the school curriculum or extracurricular activities, (2) anti-littering messages on vehicles, bill boards, etc., (3) mass media campaigns (print and electronic), (4) cleanup campaigns that provide information about how litter can be harmful to human health, wildlife or the environment.

Prompts (or persuasive communication) are written, spoken or visual messages designed to persuade people to change their behavior. They act as a reminder of what to do and what not to do, because they are signals of recommended or desired behavior. They include signs to remind people to behave in an environmental friendly manner. The idea behind prompts is that a person will not litter if a prompt with a clear instruction is given (Geller et al., 1977; Reiter \& Samuel, 1980). Verbal information delivers the same types of information as written messages, but in face to face contracts. Written prompts are the most popular medium used by researchers. An example of a written prompt is "please dispose properly" written on sachets of water. Visual prompts are shown in movies and TV commercials.

Commitment involves obtaining promises or agreements from people to change their behavior. For example, one can obtain from a litterbug a commitment not to litter throughout a specified period. The commitment may be written and explicit or verbal. Environmental design includes availability and number of trash receptacles, attractive design of trash receptacles, and the placement and accessibility of trash receptacles. It is believed that the failure to provide trash receptacles will encourage people to litter.

Consequence strategies for reducing littering include rewards, feedbacks, and penalties (fines or taxes). While rewards can be applied ex-ante, penalties are applied ex-post. Rewards, 
which may be monetary or non-monetary, include direct subsidies, reduction or waiving of fees, gifts, prizes and awards. The advantages of this technique are that (1) it is less coercive, (2) it is less intrusive and (3) it is less likely to alienate subjects than mandatory approaches. Penalties involve regulation backed up by sanctions. Lehman and Geller (2004) note that each technique has its benefits, but the greatest impact results from using multiple techniques simultaneously.

\section{RESULTS AND DISCUSSION}

This paper identifies littering as a subject of inquiry studied by both environmental economists and social/environmental psychologists, each using a different theoretical and analytical toolkit. While economists see littering as an externality problem or a market failure using the theory of externalities, psychologists see it as a social behaviour problem and employ such theories as the theory of reasoned action, the theory of planned behaviour and the broken windows theory.

Regardless of the discipline, both theories have common research questions: What factors affect littering behavior and how can it be curtailed? While economists identify the divergence between private and social costs of production and/or consumption of litter-generating products as the cause of littering, psychologists identify attitude towards littering, the subjective norm, the perceived behavioural control and the state of the environment-whether already littered or clean-as the causes of littering. To control littering, economists advocate the use of advance disposal fee, recycling subsidy and deposit-refund system, whereas psychologists recommend the use of information/ education, messages/prompts, commitment, environmental design, and modeling and demonstrations. Among the economic instruments, deposit-refund system is found to be the most effective and the best instrument that can achieve the social optimum in the presence of massive littering (Dinan, 1993; Fullerton \& Kinnaman, 1995; Walls, 2011). However, no instrument is identified as the best or most effective in the psychologist's toolkit.

Psychological measures are commonly applicable to such smaller settings as school premises, offices, factories, and market places, while economic measures are mostly applicable to such larger settings as cities, states or the entire country. In sum, the psychological approach to controlling littering is narrower compared to economic instruments. Although they can help reduce certain types of littering in certain types of settings, psychological instruments cannot be as effective as economic instruments in controlling litter items that involve a national or state setting. Besides, economic instruments provide financial incentives to motivate antilittering behaviour.

\section{CONCLUSION}

The main objective of this paper is to investigate littering and its solutions. To achieve this objective, the paper adopts interdisciplinary theory-triangulation approach to review theories concerning littering. It concisely reviews the economist's and the psychologist's approaches to littering and their respective solutions.

Despite the plethora of research extolling the virtues of economic approaches to litter control, their real-world application has not caught on. One of the factors responsible for this is the implementation costs and difficulty. The economic instruments are costlier than the psychological instruments, because the former covers a larger setting and entails a lot of bureaucracies. Since there is no such thing as a free lunch, every measure of litter control must involve a cost. An option for policy makers is to minimize those costs associated with implementing economic instruments.

To better understand littering and find appropriate solutions to it, studies on littering should consider looking at littering holistically from this interdisciplinary perspective. Both the economist's and the psychologist's approaches to litter control should be synthesized for sustainable waste management. 
Researchers need to incorporate this interdisciplinary perspective in the studies of litter or littering behavior and its control in order to gain a holistic understanding of the problem. However, policy makers need to consider the available financial resources and the multifarious views of litter in policies relating to litter.

\section{REFERENCES}

1. Ajzen, I. (1991). The theory of planned behavior. Organization Behavior and Human Decision Processes, 50(2), 179-211. https://doi.org/10.1016/07495978(91)90020-T

2. Ajzen, I. (1985). From intentions to actions: A theory of planned behaviour. In J. Kuhl \& J. Beckman (Eds.), Action-Control: From Cognition to Behaviour (pp. 11-39). Heidelberg: Springer. Retrieved from https://link.springer.com/chapter/10.1007/978-3-642-69746-3_2

3. Andersen, M. S. (2001). Economic instruments and clean water: Why institutions and policy design matter (34 p.). Organization for Economic Cooperation and Development. Paris.

4. Calver, H. N. (1959). Litter and the public health. Public Health Reports (1896-1970), 74(5), 387-391. Retrieved from https://www.ncbi.nlm.nih.gov/ pubmed/13658326

5. Carlson, A. E. (2001). Recycling norms. California Law Review, I89(5), 1231-1300. Retrieved from https://scholarship.law.berkeley. edu/cgi/viewcontent.cgi? article $=1$ 440\&context $=$ californialawreview

6. Case, K. E., Fair, R. C., Gartner, M., \& Heather, K. (1999). Economics. London: Prentice-Hall.

7. Cialdini, R. B., Reno, R. R., \& Kallgren, C. A. (1990). A focus theory of normative conduct: Recycling the Concept of Norms to Reduce Littering in Public Places. Journal of Personality and Social psychology, 58(6), 10151026. https://psycnet.apa.org/ doi/10.1037/0022-3514.58.6.1015

8. Dinan, T. M. (1993). Economic efficiency effects of alternative policies for reducing waste disposal. Journal of Environmental
Economics and Management, 25(3), 242-256. https://doi.org/10.1006/ jeem.1993.1046

9. Egunjobi, L. (2009). Our gasping cities. Inaugural Lectures 1998 2002 (Vol. 2) Ibadan: Ibadan University Press.

10. Eugine, T. (2004). Environmental economics. New Delhi: Vrinda Publications (P) Ltd.

11. Finnie, W. C. (1973). Field experiments in litter control. Environmental and Behaviour, 5(2), 123-144. https://doi.org/10.1177\% 2F001391657300500201

12. Fishbein, M., \& Ajzen, I. (1975). Belief, attitude, intention, and behaviour: An Introduction to Theory and Research. Reading, MA: Addison-Wesley.

13. Fullerton, D., \& Kinnaman, T. C. (1995). Garbage, recycling, and illicit burning or dumping. Journal of Environmental Economics and Management, 29(1), 78-91. https:// doi.org/10.1006/jeem.1995.1032

14. Geller, E. S., Witmer, J. E., \& Tuso, M. A. (1977). Environmental interventions for litter control. Journal of Applied Psychology, 62(3), 344-351. https://psycnet. apa.org/doi/10.1037/00219010.62.3.344

15. Grasmick, H. G., Bursik, R. J., \& Kinsey, K. A. (1991). Embarrassment as deterrents to non-compliance with the law: The case of an anti-littering campaign. Environmental and Behaviour, 23(2), 233251. https://psycnet.apa.org/ doi/10.1177/0013916591232006

16. Keep America Beautiful (KAB) (2009). Littering behaviour in America: Results of a national study.

17. Keizer, K., Linderberg, S., \& Steg, L. (2008). The spreading of disorder. Science, 322, 16811685. https://doi.org/10.1126/science.1161405

18. Lehman, P. K., \& Geller, E. S. (2004). Behavior analysis and environmental protection: Accomplishments and potential for more. Behavior and Social Issues, 13(1), 12-32. https://doi. org/10.5210/bsi.v13i1.33

19. National Environmental Standards and Regulations Enforcement Agency (2009). National Environmental (Sanitation and Wastes Control) Regulations, 2009. Federal Republic of Nigeria Official Gazette, 96(60).

20. Pigou, A. C. (1920). The economics of welfare. London: Macmillan and Co.

21. Rege, M., \& Telle, K. (2001). An experimental investigation of social norms (Discussion Paper No 310). Statistics Norway, Research Department, October.

22. Reiter, S. M., \& Samuel, W. (1980). Littering as a function of prior litter and the presence or absence of prohibitive signs. Journal of Applied Social Psychology, 10(1), 45-55. http://dx.doi. org/10.1111/j.1559-1816.1980. tb00692.x

23. Robinson, J., \& Ryan, S. (2002). A review of economic instruments for environmental management in Queensland. CRS for Coastal Zone, Estuary and Waterway Management.

24. Selby, H. (2012, July 13). Indiscriminate littering contributes to flood disasters. The Chronicle.

25. Sibley, C., \& Liu, J. (2003). Differentiating active and passive littering: A two-stage process model of littering behaviour in public places. Environment and Behavior, 35(3), 415-433. 
https://doi.org/10.1177\% 2F0013916503035003006

26. Solow, R. M. (1972). The economist's approach to pollution and its control. Social Science, 47(1), 15-25.

27. Stavins, R. N. (2001). Experience with market-based environmental policy instruments. In K-G. Maler \& J. Vincent (Eds.), The Handbook of Environmental Economics. Amsterdam: North-Holland/ Elsevier Service.

28. Tietenberg, T., \& Lewis, L. (2009). Environmental and natural resource economics (8th ed.). Boston: Pearson.

29. Thomas, J. M., \& Callan, S. J. (2010). Environmental economics: Applications, policy, and theory (5th ed.). Mason: South-Western Cengage Learning.

30. USEPA (2001). The United States experience with economic incentives for protecting the environment. National Centre for Environmental Economics. Washington, D.C.

31. Walls, M. (2011). Deposit-refund systems in practice and theory
(Resources for the Future Discussion Paper, 11-47).

32. Wever, R., Gutter, N., \& Silvester, S. (2006). Prevention of littering through packaging design: A support tool for concept generation. In Proceedings of TMCE (pp. 1391-1403). Retrieved from https://repository.tudelft.nl/islandora/object/ uuid\%3A4955bc54-5944-4e42a505-bf88ed395cd2

33. Wilson, J. Q., \& Kelling, G. E. (1982). The police and neighbourhood safety: Broken windows. Atlantic Monthly, 249(3), 29-38. 